\title{
Development and Validation of Stability-Indicating Liquid Chromatographic Assay for Rifaximin (An Antibiotic) in Bulk and Pharmaceutical Dosage Forms
}

\author{
M. MATHRUSRI ANNAPURNA*, B. SAI PAVAN KUMAR, \\ B. VENKATESH and J. RAJ PRAKASH
}

Department of Pharmaceutical Analysis \& Quality Assurance, GITAM, Institute of Pharmacy, GITAM University, Visakhapatnam, India mathrusri2000@yahoo.com

Received 31 January 2014 / Accepted 19 February 2014

\begin{abstract}
An isocratic reversed-phase high-performance liquid chromatographic method was developed and validated for the determination of Rifaximin. Chromatographic separation was achieved on a $\mathrm{C}_{18}$ column using an aqueous tetra butyl ammonium hydrogen sulphate $(10 \mathrm{mM})(\mathrm{pH}$ 3.37): acetonitrile $(40: 60, \mathrm{v} / \mathrm{v})$, with flow rate $1.2 \mathrm{~mL} / \mathrm{min}$ (UV detection at $441 \mathrm{~nm})$. Linearity was observed in the concentration range of $0.1-200 \mu \mathrm{g} / \mathrm{mL}\left(\mathrm{R}^{2}=0.9999\right)$. The limit of quantitation was found to be $0.0794 \mu \mathrm{g} / \mathrm{mL}$ and the limit of detection was found to be $0.0241 \mu \mathrm{g} / \mathrm{mL}$. Rifaximin was subjected to stress conditions of degradation in aqueous solutions including acidic, alkaline, oxidation, photolysis and thermal degradation. The forced degradation studies were performed by using $\mathrm{HCl}, \mathrm{NaOH}, \mathrm{H}_{2} \mathrm{O}_{2}$, thermal and UV radiation. Rifaximin is more sensitive towards acidic conditions in comparison to oxidation and very much resistant towards alkaline, thermal and photolytic degradations. The method was validated as per ICH guidelines. The method is simple, specific, precise, robust and accurate for the determination of Rifaximin in pharmaceutical formulations.
\end{abstract}

Keywords: RP-HPLC, Rifaximin, Stability-indicating, Validation, ICH

\section{Introduction}

Rifaximin $^{1}$ (RFX) is benzimdazole derivative and chemically it is a $2 \mathrm{~S}, 16 \mathrm{Z}, 18 \mathrm{E}$, 20S,21S,22R,23R,24R,25S,26S,27S, 5, 6, 21, 23, 25- penta hydroxy-27-methoxy-2,4,11, 16, 20,22,24,26,- octa methyl-2,. 7-epoxy penta deca-[1,11,13]trienimino) benzofuro[4,5-e] pyrido[1,2-a]-benzimidazole-1, $15(2 \mathrm{H})$ - dione,25acetate. It is a structural analog of Rifampin. Rifaximin (Figure 1) is a newer antibiotic, used for the treatment of patients (more than 12 years of age) with traveller's diarrhoea caused by non-invasive strains of Escherichia coli ${ }^{2}$. 


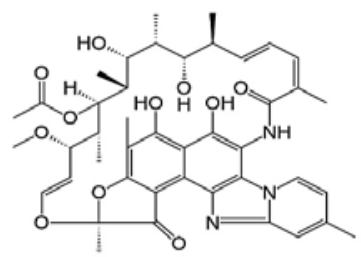

Figure 1. Chemical structure of Rifaximin

RFX is a product of synthesis of Rifamycin, an antibiotic with low gastrointestinal absorption and good antibacterial activity ${ }^{3}$. Rifaximin binds to the beta-subunit of bacterial DNA-dependent RNA polymerase and prevents catalysis of polymerization of deoxyribonucleotides into a DNA strand. As a result, bacterial RNA synthesis is inhibited. In vitro studies of RFX have demonstrated broad-spectrum coverage including Gram-positive, Gram-negative, and anaerobic bacteria as well as a limited risk of bacterial resistance ${ }^{4}$. Furthermore, RFX does not bind to RNA polymerase in eukaryotic cells, thus human cell production is not affected. Compared with other antibiotics, RFX has a lower rate of fecal pathogenic eradication, so depletion of normal gastrointestinal flora is reduced ${ }^{5}$. Methods reported for the determination of RFX in pharmaceutical dosage forms and biological fluids include RP-HPLC ${ }^{6-9}$, LC-MS $^{10-13}$ and spectrophotometric ${ }^{14-15}$ methods have been developed for the determination of RFX in pharmaceutical formulations and biological fluids. Impurity profiles of Rifaximin were also studied by using Diagnostic fragment-ion-based extension strategy (DFIBES) and derivative resolution of UV spectra ${ }^{16-17}$. In the present work we developed simple, rapid, precise and accurate robust liquid chromatographic method for the determination of RFX tablets. Previous reported methods have from one or other disadvantages and therefore the authors have developed a novel stability indicating liquid chromatographic method which was validated as per ICH guidelines ${ }^{18}$.

\section{Experimental}

Rifaximin standard (purity $\geq 99.0 \%$ ) was obtained from Torrent Pharmaceuticals Limited, India). Acetonitrile (HPLC grade), sodium hydroxide $(\mathrm{NaOH})$ and hydrochloric acid $(\mathrm{HCl})$ and Hydrogen peroxide $\left(\mathrm{H}_{2} \mathrm{O}_{2}\right)$ were obtained from Merck (India). Rifaximin is available (Label claim: $200 \mathrm{mg}$ ) with brand names RCIFAX (Lupin) and TORFIX (Torrent). All chemicals were of analytical grade and used as received.

\section{Preparation of buffer solution}

The mobile phase was prepared by accurately weighing and transferring $3.3954 \mathrm{~g}$ of tetra butyl ammonium hydrogen sulphate (TBAHS) $(10 \mathrm{mM})(\mathrm{pH} 3.37)$ in to a $1000 \mathrm{~mL}$ volumetric flask, dissolving and diluting to volume with HPLC grade water.

\section{Preparation of rifaximin stock solution}

Rifaximin stock solution $(1000 \mu \mathrm{g} / \mathrm{mL})$ was prepared by accurately weighing $25 \mathrm{mg}$ of RFX in a $25 \mathrm{~mL}$ volumetric flask with mobile phase. Working standard solutions were prepared on a daily basis from the stock solution in a solvent mixture of TBAHS (pH 3.37) and acetonitrile $(40: 60, \mathrm{v} / \mathrm{v})$. Solutions were filtered through a $0.45 \mu \mathrm{m}$ membrane filter prior to injection.

\section{Instrumentation and chromatographic conditions}

Chromatographic separation was achieved by using a Shimadzu Model CBM-20A/20 Alite HPLC system, equipped with SPD M20A prominence photodiode array detector with C18 $(250 \mathrm{~mm} \times 4.6 \mathrm{~mm}$ i.d., $5 \mu \mathrm{m}$ particle size $)$ column maintained at $25^{\circ} \mathrm{C}$. Isocratic elution was 
performed using tetra butyl ammonium hydrogen sulphate (TBAHS) ( $\mathrm{pH} \mathrm{3.37)} \mathrm{and}$ acetonitrile $(40: 60, \mathrm{v} / \mathrm{v})$. The overall run time was $10 \mathrm{~min}$ and the flow rate was $1.2 \mathrm{~mL} / \mathrm{min}$. $20 \mu \mathrm{L}$ of sample was injected into the HPLC system.

\section{Forced degradation studies}

The study was intended to ensure the effective separation of RFX and its degradation peaks of formulation ingredients at the retention time of RFX. Separate portions of drug product and ingredients were exposed to the following stress conditions to induce degradation. Forced degradation studies were performed to evaluate the stability indicating properties and specificity of the method ${ }^{19}$. All solutions for use in stress studies were prepared at an initial concentration of $1 \mathrm{mg} / \mathrm{mL}$ of RFX and refluxed for $30 \mathrm{~min}$ at $80{ }^{\circ} \mathrm{C}$. All samples were then diluted in mobile phase to give a final concentration of $10 \mu \mathrm{g} / \mathrm{mL}$ and filtered before injection.

\section{Acidic and alkaline degradation studies}

Acid decomposition was carried out in $0.1 \mathrm{M} \mathrm{HCl}$ at a concentration of $1.0 \mathrm{mg} / \mathrm{mL} \mathrm{RFX}$ and after refluxation for $30 \mathrm{~min}$ at $80^{\circ} \mathrm{C}$ the stressed sample was cooled, neutralized and diluted with mobile phase. Similarly stress studies in alkaline conditions were conducted using a concentration of $1.0 \mathrm{mg} / \mathrm{mL}$ in $0.1 \mathrm{M} \mathrm{NaOH}$ and refluxed for $30 \mathrm{~min}$ at $80{ }^{\circ} \mathrm{C}$. After cooling the solution was neutralized and diluted with mobile phase.

\section{Oxidation degradation studies}

Solutions for oxidative stress studies were prepared using $3 \% \mathrm{H}_{2} \mathrm{O}_{2}$ at a concentration of $1 \mathrm{mg} / \mathrm{mL}$ of RFX and after refluxation for $30 \mathrm{~min}$ at $80{ }^{\circ} \mathrm{C}$ on the thermostat the sample solution was cooled and diluted accordingly with the mobile phase.

\section{Thermal degradation studies}

For thermal stress testing, the drug solution $(1 \mathrm{mg} / \mathrm{mL})$ was heated in thermostat at $80{ }^{\circ} \mathrm{C}$ for $30 \mathrm{~min}$, cooled and used.

\section{Photolytic degradation studies}

The drug solution $(1 \mathrm{mg} / \mathrm{mL})$ for photo stability testing was exposed to UV light for $4 \mathrm{~h} \mathrm{UV}$ light $(365 \mathrm{~nm})$ chamber and analyzed.

\section{Method Validation}

The method was validated for the following parameters: system suitability, linearity, limit of quantitation (LOQ), limit of detection (LOD), precision, accuracy, selectivity and robustness.

\section{Linearity}

Linearity test solutions for the assay method were prepared from a stock solution at different concentration levels $(0.1-200 \mu \mathrm{g} / \mathrm{mL})$ of the assay analyte concentration and $20 \mu \mathrm{L}$ of each solution was injected in to the HPLC system and the peak area of the chromatogram obtained was noted. The calibration curve was plotted by taking the concentration on the $\mathrm{x}$-axis and the corresponding peak area on the $\mathrm{y}$-axis. The data was treated with linear regression analysis method.

\section{Precision}

The intra-day precision of the assay method was evaluated by carrying out 9 independent assays of a test sample of RFX at three concentration levels $(10,20$ and $50 \mu \mathrm{g} / \mathrm{mL})(\mathrm{n}=3)$ against a qualified reference standard. The $\%$ RSD of three obtained assay values at three 
different concentration levels was calculated. The inter-day precision study was performed on three different days i.e. day 1 , day 2 and day 3 at three different concentration levels $(10,20$ and $50 \mu \mathrm{g} / \mathrm{mL})$ and each value is the average of three determinations $(\mathrm{n}=3)$. The $\%$ RSD of three obtained assay values on three different days was calculated.

\section{Accuracy}

The accuracy of the assay method was evaluated in triplicate at three concentration levels $(80,100$ and $120 \%)$ and the percentage recoveries were calculated. Standard addition and recovery experiments were conducted to determine the accuracy of the method for the quantification of RFX in the drug product. The study was carried out in triplicate at 18,20 and $22 \mu \mathrm{g} / \mathrm{mL}$. The percentage recovery in each case was calculated.

\section{Robustness}

The robustness of the assay method was established by introducing small changes in the HPLC conditions which included wavelength (439 and $443 \mathrm{~nm}$ ), percentage of acetonitrile in the mobile phase (58 and 62\%) and flow rate $(1.1$ and $1.3 \mathrm{~mL} / \mathrm{min})$. Robustness of the method was studied using six replicates at a concentration level of $20 \mu \mathrm{g} / \mathrm{mL}$ of RFX.

\section{Analysis of marketed formulations}

The content of 25 tablets (each containing $100 \mathrm{mg}$ of RFX) was mixed and quantity equivalent to $25 \mathrm{mg}$ of drug weighed accurately and dissolved in mobile phase in a $25 \mathrm{~mL}$ volumetric flask, sonicated and filtered. The filtrate was diluted as per the requirement and $20 \mu \mathrm{L}$ solution of each of marketed formulations (RCIFAX and TORFIX) was injected in to the HPLC system for conducting the assay.

\section{Results and Discussion}

A reversed-phase liquid chromatographic technique was developed to quantitate Rifaximin in pharmaceutical dosage forms. No stability indicating liquid chromatographic method was reported earlier. A detailed comparative study of the previously published methods with the present method was discussed in Table 1 . Satisfactory resolution was achieved with use of a mixture of TBAHS and acetonitrile (40:60, v/v) (Figure 2) and C18 column was adopted for the analysis as it has provided a better separation of the analytes. UV detection was carried out at $441 \mathrm{~nm}$ (PDA detector).

Table 1. Comparison of the performance characteristics of the present HPLC method with the published methods

\begin{tabular}{ccccc}
\hline Method /Reagent & $\begin{array}{c}\lambda \\
\mathrm{nm}\end{array}$ & $\begin{array}{c}\text { Linearity, } \\
\mu \mathrm{g} / \mathrm{mL}\end{array}$ & Comments & Ref. \\
\hline $\begin{array}{c}\text { (HPLC) Methanol: } \\
\text { phosphate buffer } \\
(70: 30, \mathrm{v} / \mathrm{v})\end{array}$ & 293 & $5-30$ & $\begin{array}{c}\text { Very narrow linearity } \\
\text { range } \\
\text { (UV/visible detector) }\end{array}$ & {$[6]$} \\
\hline $\begin{array}{c}\text { (HPLC) Acetonitrile: } \\
\text { Ammonium Acetate } \\
(85: 15, \mathrm{v} / \mathrm{v})\end{array}$ & 236 & $5-50$ & $\begin{array}{c}\text { Very narrow linearity } \\
\text { range } \\
\text { (UV/visible detector) }\end{array}$ & {$[7]$} \\
\hline $\begin{array}{c}\text { (HPLC) Acetonitrile: } \\
\text { water: acetic acid } \\
(18: 82: 0.1, \mathrm{v} / \mathrm{v} / \mathrm{v})\end{array}$ & - & $0.10-20$ & rat serum and urine & {$[8]$} \\
\hline $\begin{array}{c}\text { (HPLC) Sodium acetate: } \\
\text { Acetonitrile }(\mathrm{pH} 4.0) \\
(35: 65, \mathrm{v} / \mathrm{v})\end{array}$ & 441 & $1.0-300$ & $\begin{array}{c}\text { Wide linearity range } \\
\text { Stability indicating } \\
\text { method (PDA detector) }\end{array}$ & {$[9]$} \\
\hline
\end{tabular}




\begin{tabular}{|c|c|c|c|c|}
\hline $\begin{array}{c}\text { (LC-ESI/MS/MS) } \\
\text { Acetic acid: Acetonitrile } \\
\text { (gradient mode) }\end{array}$ & - & $(0.5-10) 10^{-3}$ & rat serum & {$[10]$} \\
\hline $\begin{array}{c}\text { (LC-MS) } \\
\text { Ammonium acetate: } \\
\text { methanol (pH 4.32) }\end{array}$ & - & $(0.5-10) 10^{-3}$ & Human Plasma & [11] \\
\hline $\begin{array}{c}(\mathrm{LC}-\mathrm{MS}) \\
\text { Ammonium formate: } \\
\text { acetonitrile }(20: 80, \mathrm{v} / \mathrm{v})\end{array}$ & - & $(0.2-200) 10^{-4}$ & Human Plasma & [12] \\
\hline (LC-ESI-MS) & - & $(0.1-10) 10^{-3}$ & dried blood spots & {$[13]$} \\
\hline $\begin{array}{c}\text { (Spectrophotometry) } \\
\mathrm{FeCl}_{3}+\mathrm{MBTH} \\
\text { Alkaline borate buffer }\end{array}$ & $\begin{array}{l}637 \\
296\end{array}$ & $\begin{array}{l}5-25 \\
5-25\end{array}$ & $\begin{array}{c}\text { Very narrow linearity } \\
\text { range }\end{array}$ & [14] \\
\hline $\begin{array}{c}\text { (Spectrophotometry) } \\
\text { Water Methanol }\end{array}$ & $\begin{array}{l}437 \\
474 \\
\end{array}$ & $\begin{array}{l}1-200 \\
2-100\end{array}$ & Colorimetric methods & [15] \\
\hline $\begin{array}{c}\text { (HPLC) } \\
\text { TBAHS: Acetonitrile } \\
(40: 60, v / v)\end{array}$ & 441 & $0.1-200$ & $\begin{array}{l}\text { Wide linearity range } \\
\text { Stability indicating } \\
\text { method (PDA detector) }\end{array}$ & $\begin{array}{c}\text { Present } \\
\text { work }\end{array}$ \\
\hline
\end{tabular}

\section{HPLC method development and optimization}

Initially the stressed samples were analyzed using a mobile phase consisting of TBAHS: acetonitrile $(45: 55, \mathrm{v} / \mathrm{v})$ at a flow rate of $1.0 \mathrm{~mL} \mathrm{~min}^{-1}$. Under these conditions, the resolution and peak symmetry were not satisfactory and two peaks were observed, so the mobile phase was changed to TBAHS ( $\mathrm{pH} 3.37)$ : acetonitrile $(40: 60, \mathrm{v} / \mathrm{v})$ with a flow rate of $1.2 \mathrm{~mL} \mathrm{~min}^{-1}$ under which peaks were well resolved with good symmetry and sharpness. Therefore, mobile phase containing TBAHS ( $\mathrm{pH} 3.37)$ : acetonitrile $(40: 60, \mathrm{v} / \mathrm{v})$ was chosen for the best chromatographic response for the entire study.

\section{Method validation}

The typical chromatogram for RFX obtained from the extracted marketed formulation was shown in Figure 2. The calibration curve for RFX was linear over the concentration range of $0.1-200 \mu \mathrm{g} / \mathrm{mL}$ (Table 2). The data for the peak area of the drug in corresponds to the concentration was treated by linear regression analysis and the regression equation for the calibration curve (Figure 3 ) was found to be $y=17604 x-4629.7$ with correlation coefficient of 0.9999 which is nearly equals to unity.

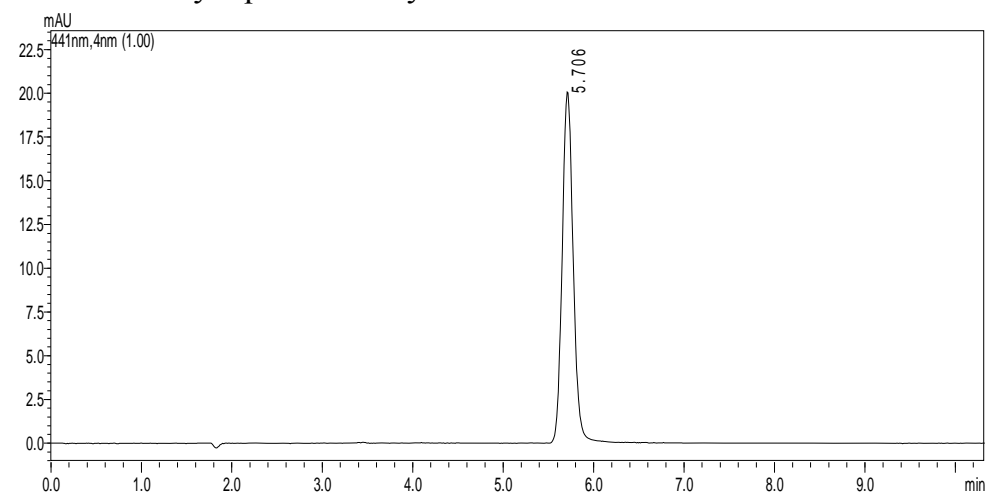

Figure 2. Representative chromatograms of Rifaximin $(10 \mu \mathrm{g} / \mathrm{mL})$ 
Table 2. Linearity of Rifaximin

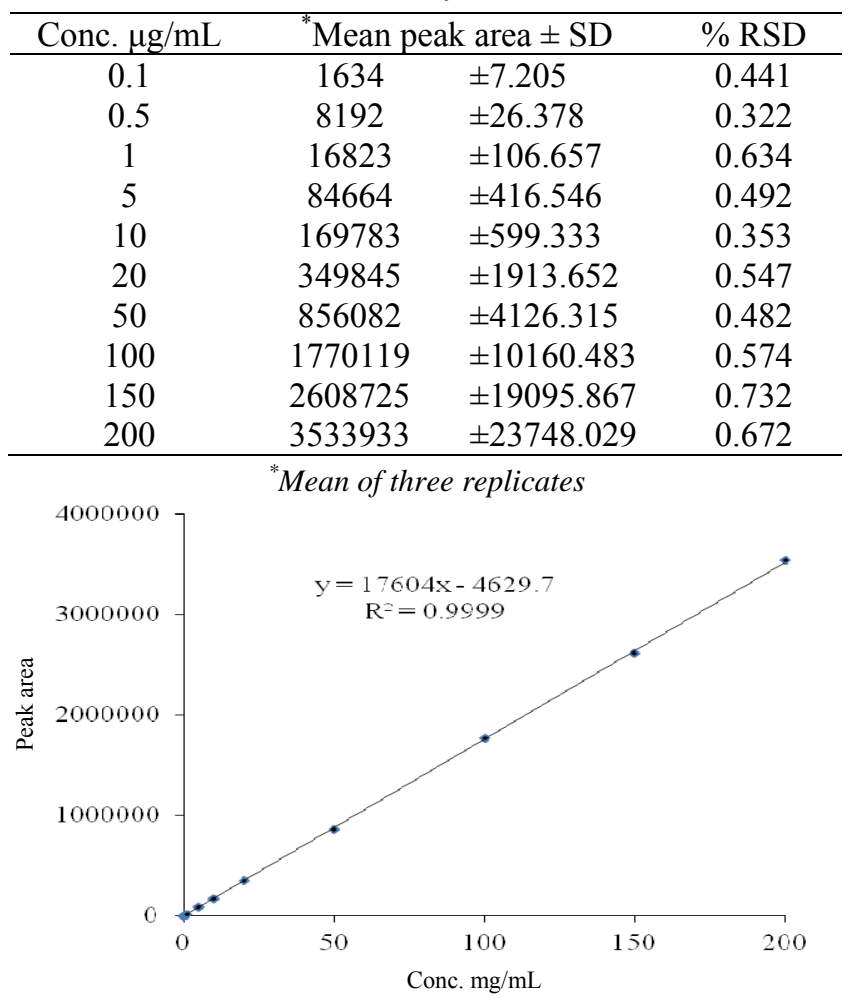

Figure 3. Calibration curve of Rifaximin

The precision of the method was determined by repeatability (intra-day precision) and intermediate precision (inter-day precision) of the RFX standard solutions. Repeatability was calculated by assaying three samples of each at three different concentration levels $(10,20$ and $50 \mu \mathrm{g} / \mathrm{mL})$ on the same day. The inter-day precision was calculated by assaying three samples of each at three different concentration levels $(10,20$ and $50 \mu \mathrm{g} / \mathrm{mL})$ on three different days. The \% RSD range was obtained as $0.2-0.4$ and $0.42-0.83$ for intra-day and inter-day precision studies respectively (Table 3 ).

Table 3. Precision and accuracy study of Rifaximin

\begin{tabular}{cccc}
\hline \multirow{2}{*}{ Conc. $\mu \mathrm{g} / \mathrm{mL}$} & Intra-day precision & Inter-day precision \\
\cline { 2 - 4 } & ${ }^{*}$ Mean peak area \pm SD $(\% \mathrm{RSD})$ & ${ }^{*}$ Mean peak area \pm SD $(\% \mathrm{RSD})$ \\
\hline 10 & $169017.00 \pm 669.06(0.4)$ & $168866 \pm 974.334(0.57)$ \\
20 & $349191.33 \pm 688.28(0.2)$ & $327740 \pm 1378.17(0.42)$ \\
50 & $854368.67 \pm 2868.32(0.34)$ & $847364 \pm 7060.75(0.83)$ \\
\hline \multicolumn{5}{c}{ Accuracy } & & \\
\hline Conc. $\mu \mathrm{g} / \mathrm{mL}$ & ${ }^{*}$ Mean peak area \pm SD (\% RSD) & Drug found $\mu \mathrm{g} / \mathrm{mL}$ & ${ }^{*}$ Recovery \% \\
\hline 18 & $307472.7 \pm 2062.288(0.66)$ & 17.72 & 98.49 \\
20 & $343376 \pm 1598.613(0.45)$ & 19.76 & 98.83 \\
22 & $377945.7 \pm 2065.988(0.54)$ & 21.73 & 98.78 \\
\hline \multicolumn{5}{c}{}
\end{tabular}


The method accuracy was proven by the recovery test. A known amount of RFX standard $(10 \mu \mathrm{g} / \mathrm{mL})$ was added to aliquots of samples solutions and then diluted to yield total concentrations as 18,20 and $22 \mu \mathrm{g} / \mathrm{mL}$ as described in Table 3 . The assay was repeated over three consecutive days. The resultant \%RSD was in the range $0.45-0.66(<2.0 \%)$ with a recovery $98.49-98.83 \%$.

The \% RSD value of assay determined for the same sample under original conditions and robustness conditions was less than 2.0\% (1.09-1.38) indicating that the developed method was robust (Table 4).

Table 4. Robustness study of Rifaximin

\begin{tabular}{ccccc}
\hline Parameter & Condition & $\begin{array}{c}\text { * Mean peak } \\
\text { area }\end{array}$ & $\begin{array}{c}\text { Statistical } \\
\text { analysis }\end{array}$ & $\begin{array}{c}\text { * Retention } \\
\text { time }\end{array}$ \\
\hline & 1.1 & 356828 & Mean $=352407.33$ & 5.706 \\
Flow rate & 1.2 & 349845 & $\mathrm{SD}=3844.56$ & 5.693 \\
mL/min & 1.3 & 350549 & $\% \mathrm{RSD}=1.09$ & 5.684 \\
Detection & 439 & 344281 & Mean $=345433$ & 5.692 \\
wavelength nm & 441 & 349845 & $\mathrm{SD}=3963.61$ & 5.693 \\
& 443 & 342173 & $\% \mathrm{RSD}=1.15$ & 5.695 \\
TBAHS: & $38: 62$ & 344243 & Mean $=349307.33$ & 5.702 \\
Acetonitrile & $40: 60$ & 349845 & $\mathrm{SD}=48118.05$ & 5.693 \\
(v/v) & $42: 58$ & 353834 & $\% \mathrm{RSD}=1.38$ & 5.684 \\
\hline
\end{tabular}

*Mean of three replicates

The system suitability test was performed to ensure that the complete testing system was suitable for the intended application. The parameters measured were peak area, retention time, tailing factor, capacity factor and theoretical plates. In all measurements the peak area varied less than $2.0 \%$, the average retention time was 5.69 minutes. The capacity factor was more than 2, theoretical plates were more than 2000 and tailing factor was less than 2 for the RFX peak. The details were shown in Table 4. The peak purity index was found to be 1.0000 . The LOQ was found to be $0.0794 \mu \mathrm{g} / \mathrm{mL}$ and the LOD was found to be $0.0241 \mu \mathrm{g} / \mathrm{mL}$.

\section{Analysis of commercial formulations (Tablets)}

The proposed method was applied for the determination of RFX in tablets (RCIFAX and TORFIX) and the results show 98.48-99.19\% recovery (Table 5) indicates that the method is selective for the assay of RFX without interference from the excipients used in these tablets.

Table 5. Analysis of Rifaximin commercial formulation (Tablets)

\begin{tabular}{ccccc}
\hline S No. & Formulation & Labeled claim mg & ${ }^{*}$ Amount found $\mathrm{mg}$ & ${ }^{*}$ Recovery $\%$ \\
\hline 1 & RCIFAX $^{\circledR}$ & 200 & 196.96 & 98.48 \\
2 & TORFIX $^{\circledR}$ & 200 & 198.38 & 99.19 \\
\hline \multicolumn{5}{c}{${ }^{*}$ Mean of three replicates }
\end{tabular}

\section{Forced degradation studies/selectivity/specificity}

The specificity of the developed method was determined by injecting sample solutions $(10 \mu \mathrm{g} / \mathrm{mL})$ which were prepared by forcibly degrading under such stress conditions as heat, light, oxidative agent, acid and base under the proposed chromatographic conditions. The stability 
indicating capability of the method was established from the separation of RFX peak from the degraded samples. The degradation of RFX was found to be very similar for both the tablets and standard. Typical chromatograms obtained following the assay of stressed samples are shown in Figure 4A-4E.
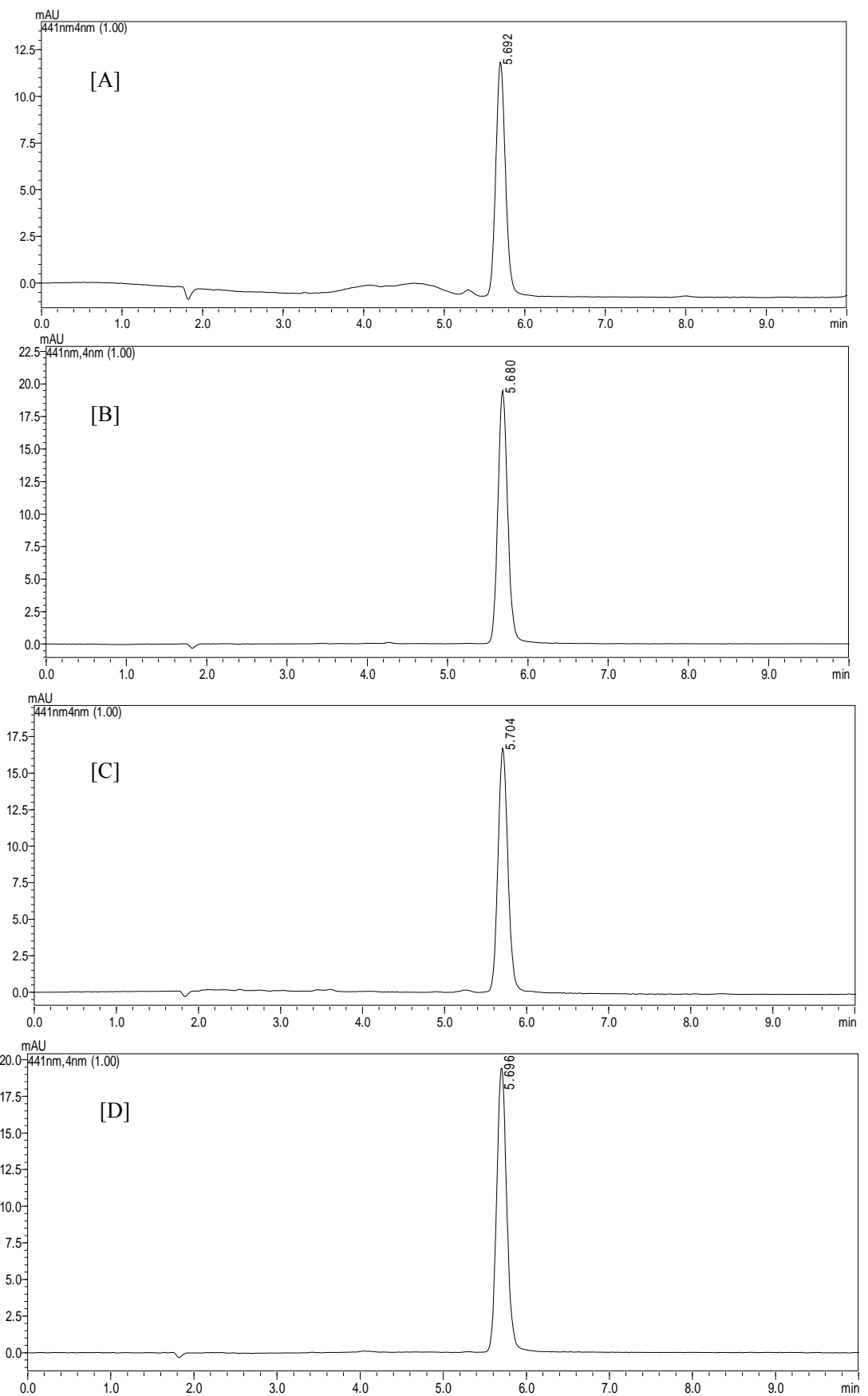


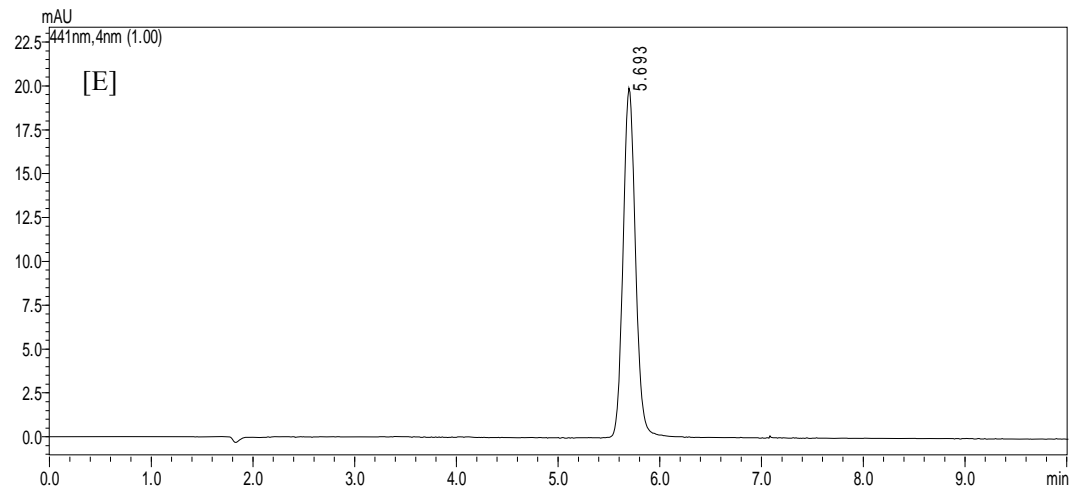

Figure 4. Representative chromatograms of Rifaximin $(10 \mu \mathrm{g} / \mathrm{mL})$ [A] Acidic [B] Alkaline [C] Oxidative [D] Thermal and [E] Photolytic degradation

RFX standard and tablet powder was found to be quite stable under dry heat conditions. A slight decomposition was seen on exposure of RFX drug solution to alkaline $(2.21 \%)$, thermal $(3.19 \%)$ and photolytic $(0.51 \%)$ conditions. During the acidic degradation, $37.94 \%$ of the drug was decomposed. The benzimidazole group present in the RFX chemical structure may be responsible for the acidic degradation. As the imidazole moiety has basic character probably it may be responsible for major degradation of Rifaximin in acidic environment. The drug has even undergone oxidative degradation (16.21\%) without any major degradant. Therefore it can be concluded that the drug is more sensitive towards oxidation and acidic conditions and the details of degradation were shown in Table 6 . The system suitability parameters for the RFX peak shows that the theoretical plates were more than 2000 and the tailing factor.

Table 6. Forced degradation studies of Rifaximin

\begin{tabular}{|c|c|c|c|c|c|}
\hline Stress Conditions & $\begin{array}{c}\text { " Mean } \\
\text { peak area }\end{array}$ & $\begin{array}{c}{ }^{*} \text { Drug } \\
\text { recovered \% }\end{array}$ & $\begin{array}{c}\text { Drug } \\
\text { decomposed } \%\end{array}$ & $\begin{array}{c}\text { Theoretical } \\
\text { plates }\end{array}$ & $\begin{array}{l}\text { Tailing } \\
\text { factor }\end{array}$ \\
\hline Standard Drug & 169783 & 100 & - & 9481.309 & 1.154 \\
\hline Acidic degradation & 105364 & 62.06 & 37.94 & 9484.383 & 1.168 \\
\hline Alkaline degradation & 166028 & 97.79 & 2.21 & 9336.099 & 1.162 \\
\hline Oxidative degradation & 142274 & 83.79 & 16.21 & 9429.806 & 1.153 \\
\hline Thermal degradation & 164362 & 96.81 & 3.19 & 9401.145 & 1.158 \\
\hline Photolytic degradation & 168913 & 99.49 & 0.51 & 9434.722 & 1.154 \\
\hline
\end{tabular}

The \% RSD of the assay of RFX from the solution stability and mobile phase stability experiments was within $2 \%$. The results of the solution and mobile phase stability experiments confirm that the sample solutions and mobile phase used during the assays were stable up to $48 \mathrm{~h}$ at room temperature and up to 3 months at $4{ }^{\circ} \mathrm{C}$.

\section{Conclusion}

The proposed stability-indicating HPLC method was validated as per ICH guidelines and can be applied for the determination of Rifaximin in pharmaceutical dosage forms. The complete separation of the analytes was accomplished in less than $10 \mathrm{~min}$ and the method can be successfully applied for kinetic studies. 


\section{Acknowledgement}

We are grateful to $\mathrm{M} / \mathrm{s}$ GITAM University, Visakhapatnam, India for providing research facilities and Torrent Pharmaceuticals Limited, India for providing the gift samples of Rifaximin.

\section{References}

1. O Neil M J, The Merck Index, Merck Research Laboratories, Whitehouse Station, New Jersey, $14^{\text {th }}$ Ed., 2006.

2. $\quad$ DuPont H, Clinical Infectious Diseases, 2007, 45(Suppl 1), S78-S84.

3. Gillis J C and Brogden R N, Drugs, 1995, 49, 467-484.

4. Bass N M, Mullen K D, Sanyal A, Poordad F, Neff G, Leevy C B, Samuel S, Muhammad Y S, Kimberly B, Todd F, Lewis T, Donald H, Shirley H, Kunal M, Audrey S, Enoch B and William P F, The New England Journal of Medicine, 2010, 362(12), 1071-1081; DOI:10.1056/NEJMoa0907893

5. Huang D B and Dupont H L, J Infection, 2005, 50(2), 97-106;

DOI:10.1016/j.jinf.2004.05.019

6. Sudha T, Hemalatha P V, Ravikumar V R, Jothi R and Radhakrishnan M, Asian J Pharm Clin Res., 2009, 2(4), 112-116.

7. Bikshal Babu K, Reshma Syed, Kalpana P and Sandhya B, Int J Res Reviews Pharm Appl Sci., 2011, 1(4), 323-333.

8. Rao R N, Shinde D D and Agawane S B, Biomed Chromatogr., 2009, 23(6), 563-567; DOI:10.1002/bmc.1149

9. Mathrusri Annapurna M, Sai Pavan Kumar B, Venkatesh B and Raj Prakash J, Drug Invention Today, 2012, 4(8), 430-434.

10. Nageswara Rao R, Mastan Vali R and Dhananjay D S, Biomed Chromatogr., 2009, 23(11), 1145-1150; DOI:10.1002/bmc.1236

11. Zhang X, Duan J, Ke Li, Zhou L and Zhai S, J Chromatogr B, 2007, 850, 348-355.

12. Challa B R, Kotaiah M R, Chandu B R, Chandrasekhar K B, Kanchanamala K, Parveen S K R and Micheal F, East Central African J Pharm Sci., 2010, 13, 78-84.

13. Nageswara Rao R, Mastan Vali R, Ramachandra B and Pawan K M, Biomed Chromatogr, 2011, 25(11), 1201-1207; DOI:10.1002/bmc.1591

14. Sudha T, Anandakumar K, Hemalatha P V, Ravikumar V R and Radhakrishnan, Int $J$ Pharm Pharm Sci., 2010, 2(1), 43-46.

15. Nanda B, Amrutansu P and Mathrusri Annapurna M, Int J Pharm Tech., 2010, 2(4), 1098-1104.

16. Corti P, Savini L, Celesti L, Cerameli G and Monotecchi L, Pharmaceutica Acta Helvetica, 1992, 67(3), 76-79.

17. Maixi Liuchao, Wan Wangchaoa and Chunpeng, Die Pharmazie, 2012, 67(4), 283-287.

18. ICH Validation of analytical procedures: Text and methodology Q2 (R1), International Conference on Harmonization, 2005.

19. ICH Stability Testing of New Drug Substances and Products Q1A (R2), International Conference on Harmonization, 2003. 